Junior Nomani, Guy Littlefair *

\title{
Evaluation of a new Short-Project Based Learning (PBL) method in an engineering 1st year programme
}

Junior Nomani is a Senior Lecturer at AUT University and has been teaching in Mechanical engineering for over 13 years in New Zealand, Australia and China universities. His teaching background covers a broad range from communication to engineering design to his main research focus of manufacturing and material science. <junior.nomani@aut.ac.nz> ORCID: 0000-0002-2916-6915
Abstract A new novel approach towards Project Based Learning (PBL) was developed for design project-based learning activities. PBL activities traditionally span in duration from a few weeks to one year. The shortened PBL project was created for a half-day practical and ran in a 1st year undergraduate engineering unit. The project involved sustainable re-design of disaster-aid relief items. The project also involved students utilising interactive 3D virtual visualisation technology known as the CAVE environment as a design development tool. This paper assesses the effectiveness of the developed short project-based learning project (SPBL) at improving student engagement. Students survey responses indicated student engagement was high from participating in the short PBL activity, realism in the project played an important role. Short PBL projects can become a positive tool in teaching and learning through the maintaining of student and cognitive engagement throughout the entire duration of the project.

Keywords CAVE, Short Project-based learning, Virtual reality 


\section{Avaliação de um novo método de Aprendizagem Baseada em Projetos (PBL) em um programa de engenharia de primeiro ano}

Guy Littlefair is an executive university leader with over 20 years' focused experience in devising and implementing strategies, objectives and policies to navigate change and effectively develop and manage the academic and research profiles, as well as the financial and $\mathrm{Hu}-$ man Resources, within large and complex Faculties and Divisions. Guy has an exceptional 30+ year record in industry, research and academia. <guy.littlefair@aut.ac.nz> ORCID: 0000-0003-2023-3605
Resumo Uma nova abordagem para a Aprendizagem Baseada em Projetos (PBL) foi desenvolvida para atividades de aprendizagem baseadas em projetos de design. As atividades PBL tradicionalmente duram de algumas semanas a um ano. $O$ projeto PBL encurtado foi criado para meio período prático e executado em uma unidade de graduação de engenharia do $1^{\circ}$ ano. 0 projeto envolveu um redesenho sustentável de itens de ajuda humanitária a desastres. 0 projeto também envolveu os alunos utilizando a tecnologia de visualização virtual 3D interativa conhecida como ambiente CAVE como uma ferramenta de desenvolvimento de design. Este artigo avalia a eficácia do projeto desenvolvido de aprendizagem baseada em projetos de curta duração (SPBL) para melhorar o envolvimento dos alunos. As respostas da pesquisa dos alunos indicaram que o envolvimento dos alunos foi alto com a participação na curta atividade PBL, o realismo no projeto desempenhou um papel importante. Projetos curtos de PBL podem se tornar uma ferramenta positiva no ensino e aprendizagem por meio da manutenção do aluno e do envolvimento cognitivo durante toda a duração do projeto.

Palavras chave CAVE, Aprendizagem baseada em projetos curtos, realidade virtual

Evaluación de un nuevo método de aprendizaje basado en proyectos cortos (PBL) en un programa de primer año de ingeniería

Resumen Se desarrolló un nuevo enfoque novedoso hacia el aprendizaje basado en proyectos (ABP) para diseñar actividades de aprendizaje basadas en proyectos. Las actividades de $A B P$ tradicionalmente tienen una duración de unas pocas semanas a un año. El proyecto abreviado de PBL se creó para una práctica de medio día y se ejecutó en una unidad de ingeniería de primer año. El proyecto implicó el rediseño sostenible de artículos de ayuda humanitaria. El proyecto también involucró a estudiantes que utilizaban tecnología de visualización virtual interactiva en 3D conocida como entorno CAVE como herramienta de desarrollo de diseño. Este documento evalúa la eficacia del proyecto de aprendizaje basado en proyectos cortos desarrollado (SPBL) para mejorar la participación de los estudiantes. Las respuestas de la encuesta de los estudiantes indicaron que la participación de los estudiantes fue alta debido a la participación en la actividad breve de PBL, el realismo en el proyecto jugó un papel importante. Los proyectos breves de ABP pueden convertirse en una herramienta positiva en la enseñanza y el aprendizaje a través del mantenimiento del compromiso cognitivo y del estudiante durante toda la duración del proyecto.

Palabras clave CAVE, Aprendizaje basado en proyectos cortos, Realidad virtual 


\section{Introduction}

Student engagement is a continually raised issue across all disciplines and levels in education. Student engagement is a complex construct, depending not only on academic and educational influences but also the students own individual background such as social and political influences (Kahu, 2013) . When there is a presence of high student engagement, the learning experience is enhanced, stimulating the student's cognition and behaviour towards ease in procurement of educational learning outcomes. Developing learning tasks to stimulate this high student engagement should be an on-going focus in any design of curriculum.

The focus of this research is to assess the level of student engagement of a half-day practical created based on project-based learning (PBL) activities. The practical was developed to improve student engagement in a 1st year engineering undergraduate materials unit. A change from the original practical was considered after students from prior unit offerings indicated in evaluate surveys, they felt less motivated and engaged. The theme was sustainable materials and sustainable design. The original task was to design and construct a bridge made of simple materials (e.g. paper, straws, Popsicle sticks) to hold the most weight while using least amount of material.

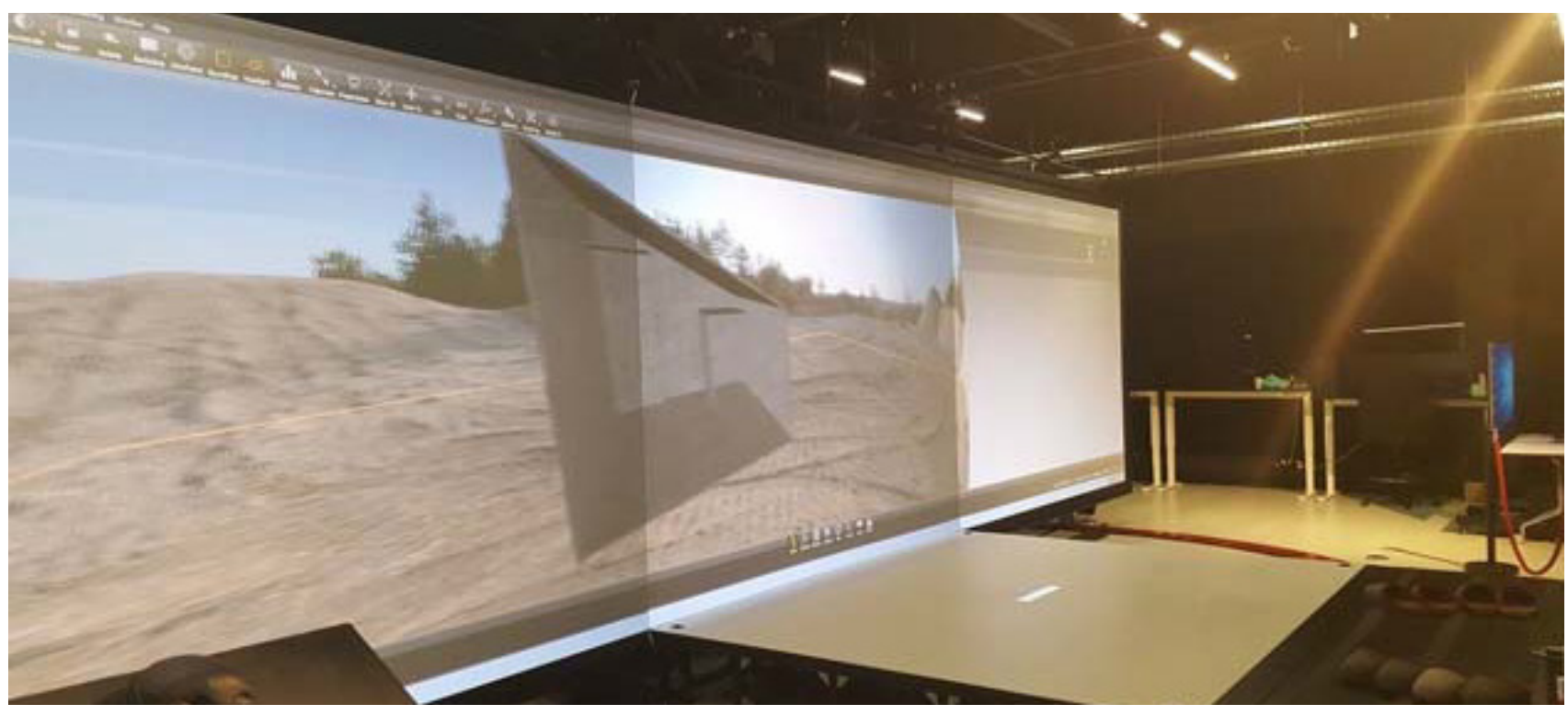

Fig 1. CAVE platform facility at Deakin University

The new practical approach was to develop the task based on project-based-learning (PBL) activities. Students would be given a real-world design challenge problem and construct a solution through research and development within a group. Numerous studies have shown support of PBL tasks towards enhancing student motivation (Bell, 2010; Blumenfeld et al., 1991; Chandrasekaran, Stojcevski, Littlefair, \& Joordens, 2013; Thomas, Utley, Hong, Korkmaz, \& Nugent, 2020). 
The new practical also provided the opportunity to utilise the newly installed technical facilities within the school at the time, as part of the practical. The CAVE was a new established virtual reality facility, installed in 2015 in CADET Building in the School of Engineering at Deakin, shown in Figure 1. The CAVE would be utilised as an interactive design visualisation tool in the new practical. Thomas (Thomas et al., 2020) and Blumenfeld et. al, (Blumenfeld et al., 1991) both commented on how the role of technology can add value to how students perceive projects in terms of interest. As quoted by Blumenfeld et. al, "Technology can contribute to how interesting and valuable students find projects" (Blumenfeld et al., 1991). The potential for developing a practical based on a project-based learning task combined with use of new technology as a design tool would lead to achieving high student engagement.

\section{Virtual Reality Background}

The CAVE referred as Automatic Virtual Environment was described by Neira et. al, (Cruz-Neira, Sandin, \& DeFanti, 1993) as an interactive virtual reality system where the observer is able to move in the virtual world and view from different angles, and to be able to reach into the space and even reshape. Virtual reality applied as teaching tool is not a new concept and has been seen extensively applied in medical education (Hoffman \& Vu, 1997). A study by Harrison et. al, (Harrison et al., 2017) demonstrated the effectiveness of virtual reality applied to the teaching of surgical hand preparation which believed the use of VR technology as a teaching tool led to improved skill acquisition and longer skill retention compared to learning by standard practice of video demonstration.

Virtual reality has also been applied in engineering education. Abulrub et. al, (Abulrub, Attridge, \& Williams, 2011) reported on the effectiveness of virtual reality applied to student formula car challenge projects, where VR technology was adapted by students as a digital prototyping tool. Their paper reported a number of positive benefits with student's use of VR technology as part of their project such as aiding in their creativity and also aiding in problem solving task. The use of VR also aided in the sharing of complex and technical information and encourage the development of effective communication skills between the student team members. It was hoped the same high level of student engagement described by Abulrub, would be replicated with current Deakin students in the proposed new practical activity task. 


\section{PBL Definition}

Project Based Learning (PBL) is defined by Thomas (Thomas et al., 2020) as a model which organises learning around projects. Thomas defines numerous important criteria for a PBL project in his review of research on Project Based Learning. One of these, is the central activities of the must involve some "transformation or construction of knowledge" meaning the project must involve some development of new understanding or new skills. If the task can be completed with already learned information or skills, then the project is simply an exercise, not a PBL project as defined by Thomas (Thomas et al., 2020).

PBL projects are complex tasks based on challenging nontrivial problems which students actively engage through asking and refining questions, discussing and researching ideas, collecting and analysing data, etc. (Blumenfeld et al., 1991). When the project involves design or some innovative or creative aspect, it is commonly referred as design-based learning DBL or project-oriented design-based learning PODBL (Chandrasekaran et al., 2013). The flow process of the various PBLs are commonly the same, however. Figure 2 displays the sequence of a typical PBL activity.

\section{START}

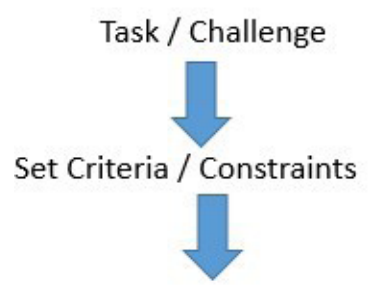

\section{Total Project Duration \\ ( 3 weeks -1 year )}

Give it a try

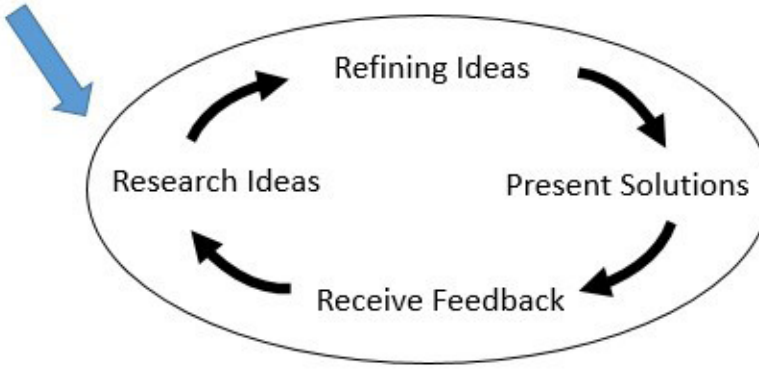

Final Proposed Solution

FINISH
Fig 2. Project-based learning (PBL) process flow diagram
Once the challenge, criteria and constraints is presented to the students, the PBL takes the form of an iterative loop where knowledge is constructed by the students through research and continual refinement of their ideas and solutions as well as receiving feedback from the teacher, whose role becomes more as a facilitator. Mills et. al, (Mills \& Treagust, 2003) commented on the duration of PBL projects in engineering undergraduate courses vary from a few weeks up to a whole year. PODBL projects run for one trimester, 11 teaching weeks in engineering undergraduate programs at Deakin University. 


\section{Designing The Short PBL Activity}

The main challenge in creating a short PBL project was creating an activity that students could engage in tasks and complete within the short timeframe, while maintaining the core elements of a PBL project such as drive, complexity and realism. The designed short PBL project captured most of the definitions of what defines a PBL project outlined by Thomas (Thomas et al., 2020), mentioned in the previous section.

The project theme was sustainability and humanitarian aid. The project was based on ShelterBox, a disaster-aid charity relief organisation, delivering disaster relief kits containing items such as tent housing, cooking equipment, sleeping mats to families and people who have been displaced from their homes due to disaster. The focus was sustainable product redesign of disaster relief items. The main task for students was product sustainable redesign of disaster relief items equipment. Student groups were each presented with a real-world disaster event where they were tasked with designing an appropriate ShelterBox kit and housing design with incorporating sustainable design features. The timeline of the activity is shown in Figure 3. The short PBL would only allow the standard PBL iterative design loop to cycle once before the final solution is proposed.

Fig 3. Short project-based learning (SPBL) sequence

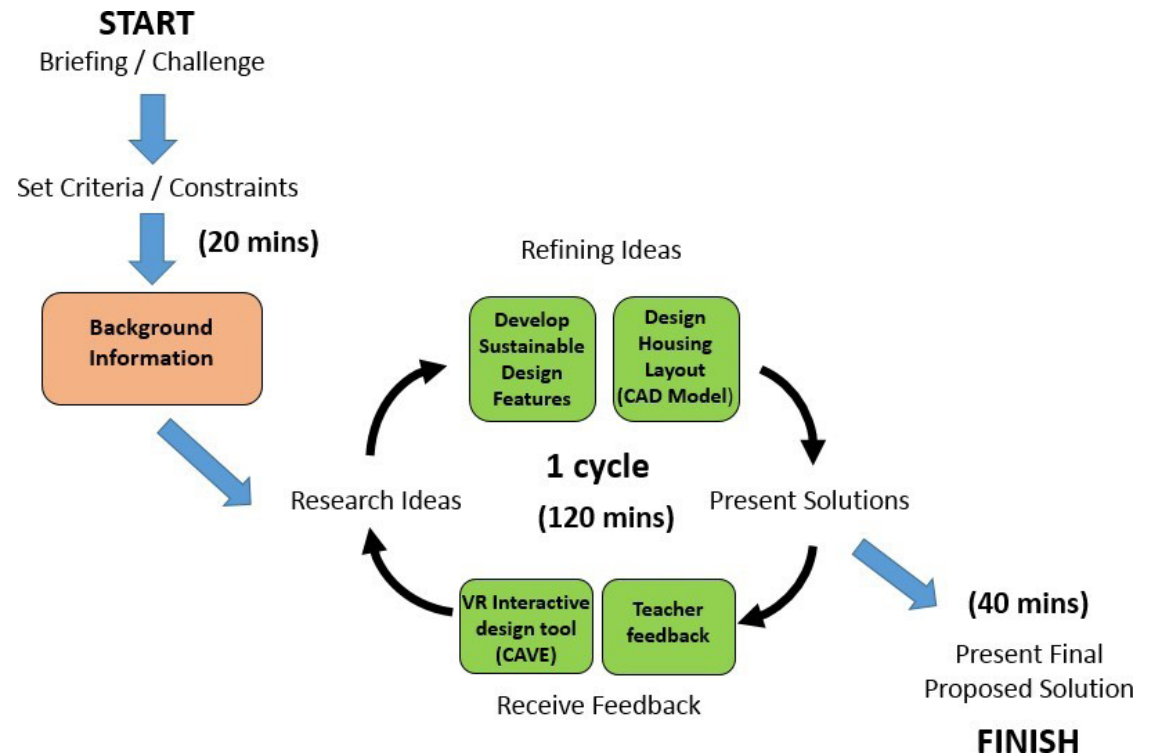

Due to time constraints, students were supplied with short background information, e.g. information about the disaster, local weather and climate to provide groups a lead on the type of equipment they would need to design. Groups could then commence researching ideas via online, developing sustainable design features and housing design layout and $C A D$ model. An example of the students presented work is shown in Figure 4. 


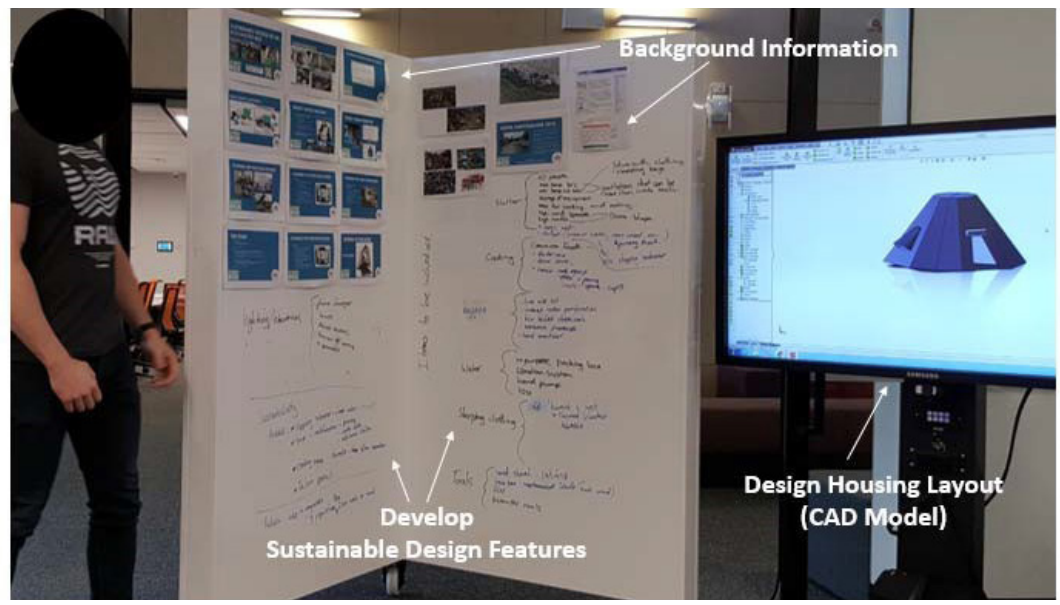

Fig 4. Produced group work for the short PBL project

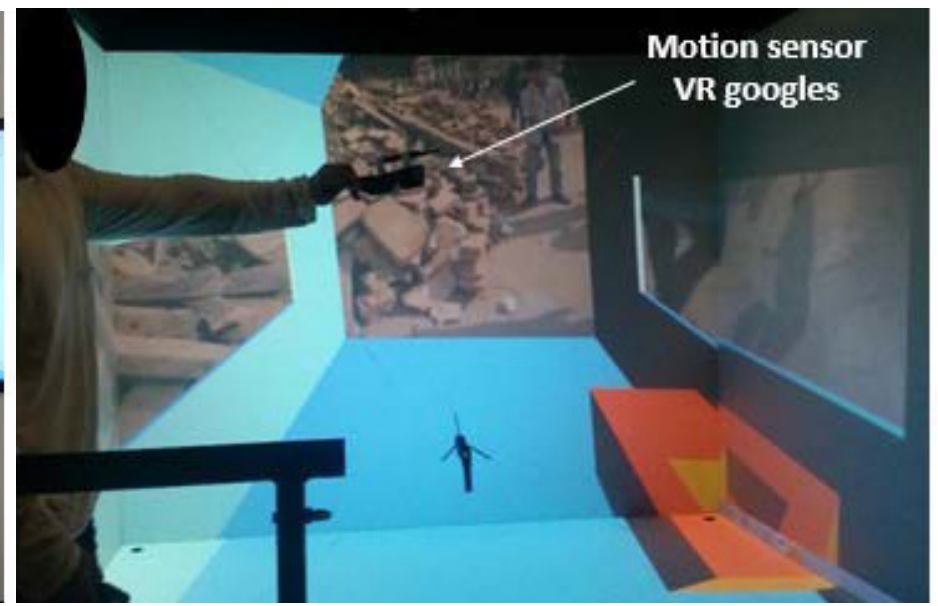

Fig 5. CAVE used for student group design visualisation

Groups made use of the CAVE as a form of technological feedback of their housing design. VR googles provided a way of tracking where students could walk and interact as if inside their housing structure. After the CAVE feedback, groups could look towards further online research and refining their housing design and sustainable design features before delivering their final proposed solution to the class as shown in Figure 6, concluding the short PBL activity.

Fig 6. Student group presenting their final proposed solution

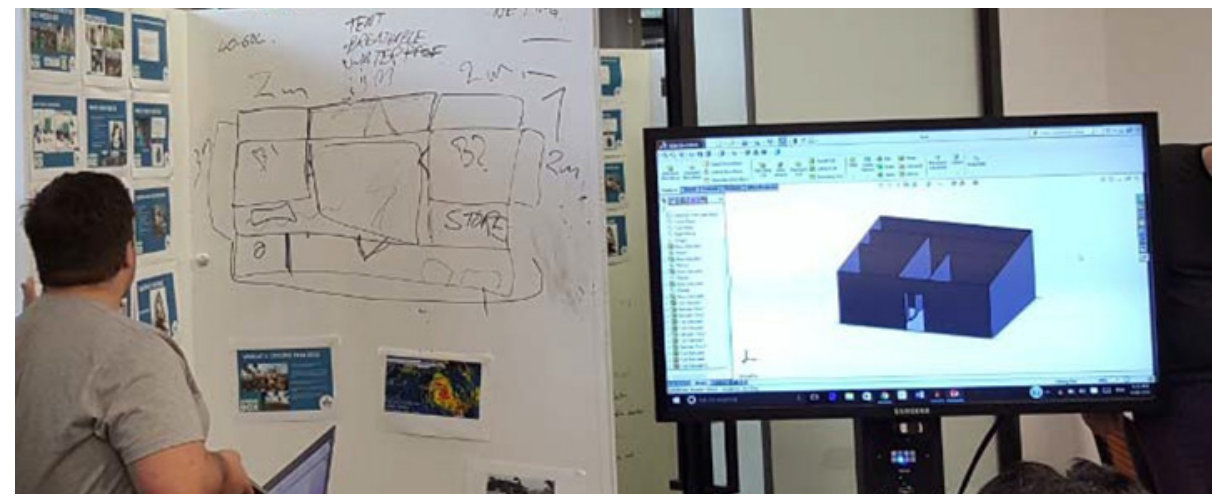

\section{Student feedback}

At the conclusion of the practical, students were asked to complete an optional survey based on assessing their experiences and level of engagement towards the short PBL. Most questions required a 'Likert' scaled response. A total of 13 students completed the survey which was conducted by an independent assessor to minimise coercion and keep responses anonymised. 


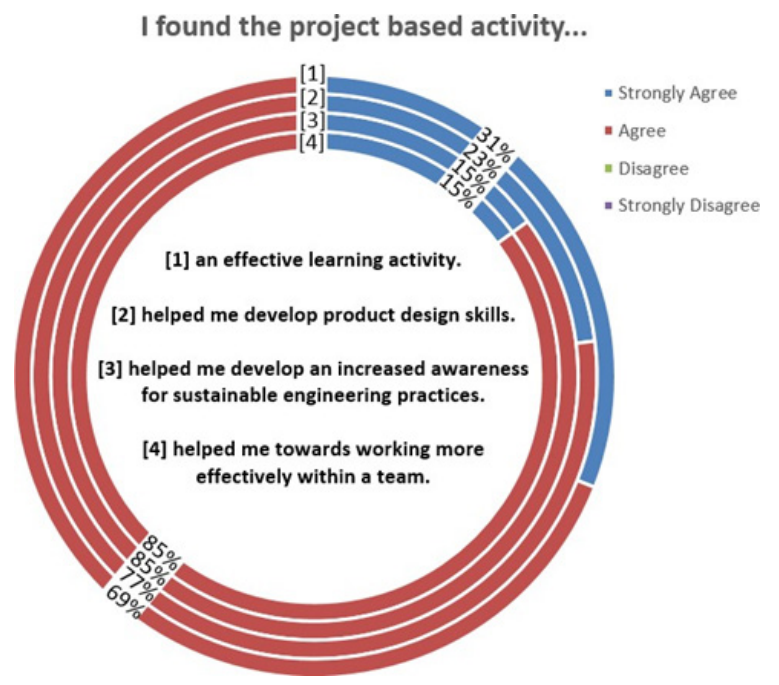

Fig 7. Survey responses - student feedback on the short PBL activity

How engaged did you feel with the activity centred around a real-world design based problem

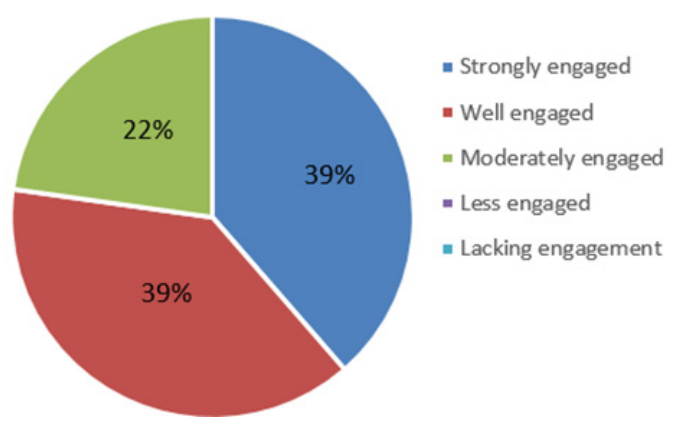

Fig 8. Survey responses - Student engagement of the PBL task
According to students who completed the survey, 31\% strongly agreed the short PBL was an effective learning activity. $23 \%$ also strongly agreed the short PBL aided in developing product design skills. Moreover, $15 \%$ of students strongly agreed the short PBL helped develop an increase awareness for sustainable engineering practices and also agreed the short PBL helped towards working more effectively in within a team, see Figure 7. Based on the $100 \%$ number of student agreed responses shown in Figure 7, there clear evidence to suggest a high student engagement was present due to the short PBL activity. After the text edit has been completed, the paper is ready for the template. Duplicate the template file by using the Save As command, and use the naming convention prescribed for the name of your paper. In this newly created file, highlight all of the contents and import your prepared text file. You are now ready to style your paper.

Students were asked further, on how engaged they were with the activity based on a real-world designbased-problem. From the responses captured in Figure 8, there was an evident relation between the degree of project realism and level of student engagement. Roughly $39 \%$ of student answered strongly engaged and $39 \%$ well engaged. The remaining $22 \%$ responded to being moderately engaged. Blumenfeld et. al, (Blumenfeld et al., 1991) suggests a valid motive for the high-level engaging number of responses, mentioning PBL projects increase students interests as they task students with solving authentic problems and working with others and creating real solutions.

When students were asked about their CAVE experience in using the interactive technology, $61 \%$ agreed use of the technology was both an effective learning tool and made students more engaged towards the learning. Moreover, $31 \%$ strongly agreed while $8 \%$ disagreed this to be true, see Figure 9. Results indicate interacting with the CAVE technology does play a role in encouraging students towards the learning. Krajicik (Krajcik, Blumenfeld, Marx, \& Soloway, 1994) believed the use of technology applied to project-based science stimulates a more authentic environment and emulating tools which experts used in reality to create artefacts. The same could be said here, where it is the sense of realism in use of the CAVE technology provides, which plays a critical role that high level of engagement for the student. Use of any technologies in PBL projects that could offer similar degrees of realism to the student, would be anticipated in having similar influences of promoting high student engagement. 
I found the use of interactive visualisation technology...

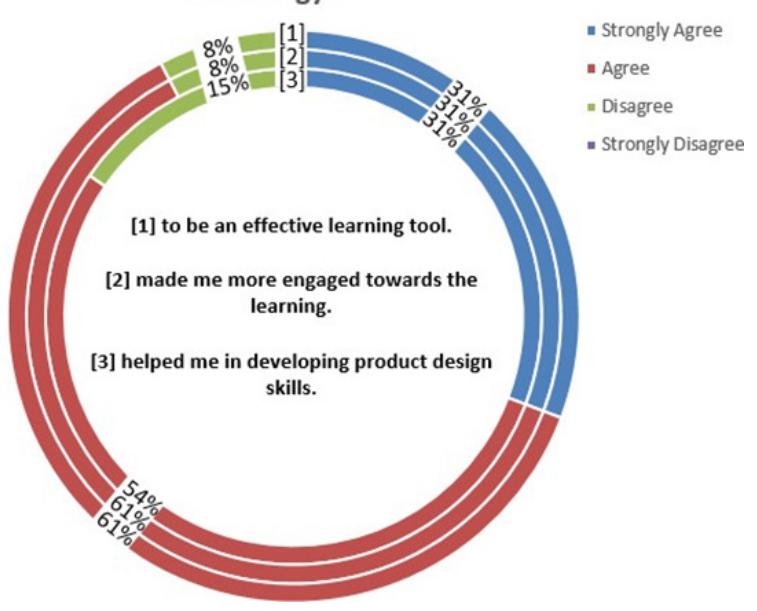

Fig 9. Survey responses - On interactive visualisation technology

Which best identifies how challenging was the project based activity?

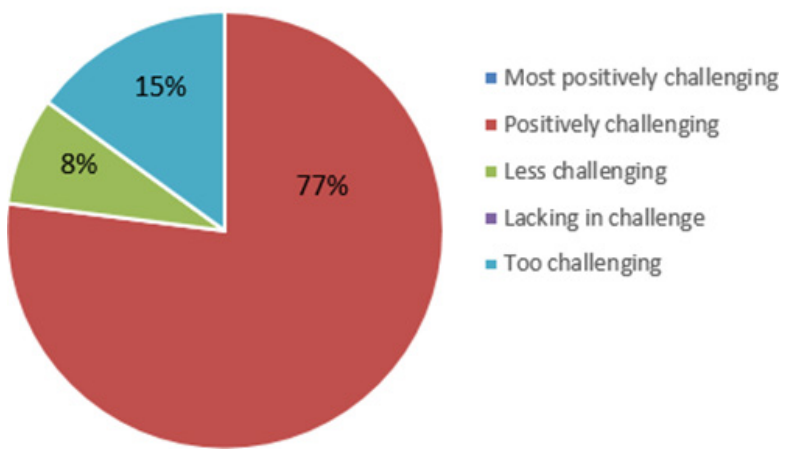

Fig 10. Survey responses - Degree of difficulty of Short PBL
When students were asked whether using the interactive technology aided in developing product design skills, 31\% responded as strongly agreed, 54\% agreed, while $15 \%$ disagreed. The increase in the number of disagreed responses could be due to the limited time availability with the CAVE. Groups were individually cycled through the CAVE and given 20-minute group user time. Perhaps individuals required more time to further develop product design skills.

Students were asked to identify how challenging was the short PBL activity from a list of responses shown in Figure 10. The majority $77 \%$ responded the PBL was positively challenging. $15 \%$ of student responses found the project too challenging, while $8 \%$ found the project task less challenging. PBL projects require a certain degree of difficulty which is challenging in a way that it stimulates the learning. Blumenfeld et. al, (Blumenfeld et al., 1991) reiterates this, suggesting students are more likely to take part in PBL projects when the projects they perceive as being valuable, challenging as well as other factors such as realism and interaction, which result in "authentic products". It could be suggested based on majority responses shown in Figure 10, that the challenging aspect of the project task was what stimulated realism and creating a positive learning environment for the student.

Students were given an option to comment on what they found to be most challenging, or what needed more challenge in the project. Figure 11 displays a summary of 10 student responses. The majority $70 \%$ of students who responded, mentioned the time constraints to complete the project being the most challenging aspect, $30 \%$ commented on various tasks in the project being the most challenging e.g. constructing the housing onto CAD drawing.

The limited time constraint was an important factor for a project-based learning activity, particularly when students are challenged with a difficult task or problem to solve. As previously stated, standard PBL projects can traditionally span between 3 weeks to 1 year in duration (Thomas et al., 2020). This extended period of time is necessary for the student in fostering cognitive engagement with the tasks or subject matter (Blumenfeld et al., 1991). It is difficult to gauge the level of cognitive engagement achieved by students who completed the short PBL project with the current data. This question would pose useful for future works tied to further development and investigation of short PBL projects. 
Comment on what you tound most challenging or what needed more challenge in the project?

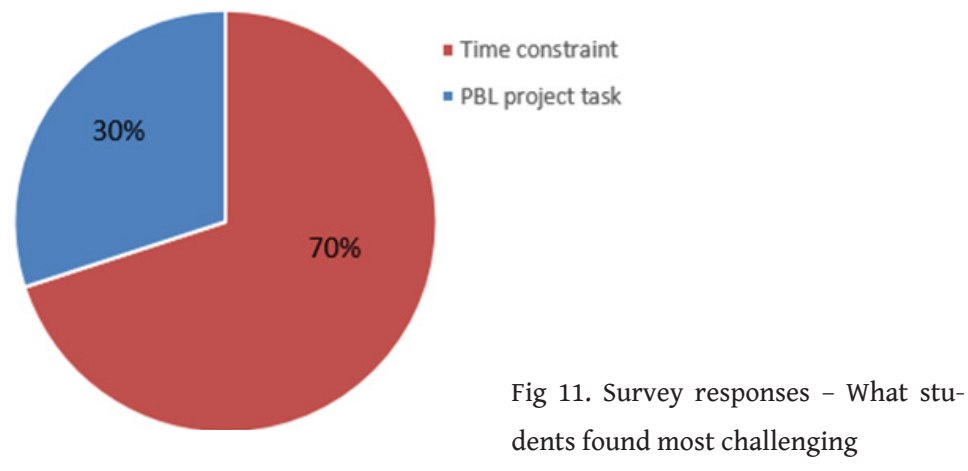

\section{Conclusion}

There is benefit from further development of short-project-basedlearning (PBL) projects designed for short duration activities such as half-day or full-day practical learning events. Students survey responses strongly indicate short PBLs are both an effective learning activity and aids creating high student engagement. One main source identified by the current study, associated with student engagement was the degree of realism which the short PBL should be based on, to create interest and value for student to be engaged. The use of interactive virtual technology such the CAVE environment utilised as a design tool, can be useful to students in enhancing the degree of realism and enhancing further student engagement.

Time to complete the short PBL project is what most student commented on being most challenging about the project. Students were given 2 working hours to complete the project which could be modified depending on the design of complexity of short PBL tasks. However, there a unique advantage offered by the short duration of short PBL project. It is often difficult to maintain a high student cognitive level engagement throughout the entire duration of any normal length PBL project. This could be due to student's loss of motivation in project overtime. This is perhaps due to the loss in interest in created novelty or variety elements within the project, originally added to create interest and value to promote student engagement. A short PBL would not yield a similar loss in motivation or interest as the time duration is considered too small. Therefore it could be claimed within the entire duration of a short PBL activity,

1. The level of student engagement is high

2. The level of cognitive engagement is high

And both are maintain at a high level throughout the entire duration of the short PBL. 


\section{References}

Abulrub, A.-H. G., Attridge, A. N., \& Williams, M. A. (2011). Virtual reality in engineering education: The future of creative learning. Paper presented at the 2011 IEEE global engineering education conference (EDUCON).

Bell, S. (2010). Project-based learning for the 21st century: Skills for the future. The clearing house, 83(2), 39-43.

Blumenfeld, P. C., Soloway, E., Marx, R. W., Krajcik, J. S., Guzdial, M., \& Palincsar, A. (1991). Motivating project-based learning: Sustaining the doing, supporting the learning. Educational psychologist, 26(3-4), 369-398.

Chandrasekaran, S., Stojcevski, A., Littlefair, G., \& Joordens, M. (2013). Project-oriented design-based learning: aligning students' views with industry needs. International journal of engineering education, 29(5), 1109-1118.

Cruz-Neira, C., Sandin, D. J., \& DeFanti, T. A. (1993). Surround-screen projection-based virtual reality: the design and implementation of the CAVE. Paper presented at the Proceedings of the 20th annual conference on Computer graphics and interactive techniques.

Harrison, B., Oehmen, R., Robertson, A., Robertson, B., De Cruz, P., Khan, R., \& Fick, D. (2017). Through the eye of the master: The use of Virtual Reality in the teaching of surgical hand preparation. Paper presented at the 2017 IEEE 5th International Conference on Serious Games and Applications for Health (SeGAH).

Hoffman, H., \& Vu, D. (1997). Virtual reality: teaching tool of the twenty-first century? Academic medicine: journal of the Association of American Medical Colleges, 72(12), 1076-1081. Kahu, E. R. (2013). Framing student engagement in higher education. Studies in higher education, 38(5), 758-773.

Krajcik, J. S., Blumenfeld, P. C., Marx, R. W., \& Soloway, E. (1994). A collaborative model for helping middle grade science teachers learn project-based instruction. The elementary school journal, 94(5), 483-497.

Mills, J. E., \& Treagust, D. F. (2003). Engineering education-Is problem-based or project-based learning the answer. Australasian journal of engineering education, 3(2), 2-16.

Thomas, J., Utley, J., Hong, S.-Y., Korkmaz, H., \& Nugent, G. (2020). A Review of the Research. Handbook of Research on STEM Education.

Recebido: 03 de março de 2021. Aprovado: 12 de abril de 2021. 